To cite this article: Ashrafiany, Hasanuddin Fatsah*, Kartin Lihawa, Nonny Basalama (2021). MINIMIZING STUDENTS' DIFFCIULTIES IN WRITING ESSAY THROUGH COGNITIVE PROCESS, International Journal of Education and Social Science Research (IJESSR) 4 (6): 63-76

\title{
MINIMIZING STUDENTS' DIFFCIULTIES IN WRITING ESSAY THROUGH COGNITIVE PROCESS
}

\author{
Ashrafiany, Hasanuddin Fatsah*, Kartin Lihawa, Nonny Basalama \\ Universitas Negeri Gorontalo Indonesia \\ *Correspondent author
}

DOI: http://dx.doi.org/10.37500/IJESSR.2021.4606

\begin{abstract}
The research objectives are to find out (1) the students' writing difficulties in writing essay (2) to find out cognitive process of writing. The research used qualitative method. The participants of this research is third semester of English Department of State University of Gorontalo who take English for Professional Context as subject. The results of data showed that (1) students' have difficulties in writing including pre writing, drafting and reviewing. (2) Students have well plan after learning argumentative essay part in including writing thesis statement, topic sentence, introduction, counter argument, supporting paragraph and conclusion. They have a good self- regulation in writing. They can managing their plan for writing started from finding topic to write a complete essay. (3) Students' essay result showed that they have improved their skill of writing. At least, minimize their difficulties in writing. They got an average score around 66- 83. It can be said that students' cognitive process in learning argumentative essay is good and it can minimize their difficulties in writing.
\end{abstract}

KEYWORDS: Writing difficulties, Argumentative essay, Cognitive process

\section{INTRODUCTION}

Writing an essay is one of students' college tasks to develop their knowledge and skill in writing. In writing essay, students need to learn how to get the interest topic for writing, how to organize the idea, how to write into a good form and consider the goals of essay itself. To get interest topic of writing, students should have many references of reading texts. After reading texts, students can select an appropriate topic by their own.

In reading text, students also used their cognitive process to analyze and comprehend the text. Flowers and Hayes (1981) stated that there are three parts in reflecting the writing included task environment, writer's long-term memory and writing process. Task environment includes all of those things outside and can influence the performance. The environment is composed of some writing instructions that determine (1) the general theme of the text to be written (Topic), its communicative goal (Audience), and (2) some motivational factors deriving from the writing situation (Motivating Cues). These things including rhetorical problem part. At the beginning of writing, the writer needs to analyze the 
appropriate topic to write and consider the goal (audience) so that the text can affect and catch readers' attention when they read it. It is important to begin writing by real world issues or reflecting personal experience which is stated and formulated into the interesting statements. This usually what happen when composing or writing process. Then, writer draw a good writing situation to support or motivate a good writing process. Once this is completed, he writer be able to start to draft a plan for the writing (text produce so far) (3), the information and knowledge from previous things be used as the reference in order to progress as well as to revise the already written text.

In relation to task environment, it also integrated to writers' long-term memory which helps the writer to store knowledge including topic, audience and various writing plans. After storing knowledge, the writer needs to have writing process which divided into three parts of planning, translating and reviewing. The planning process is retrieved from long term memory (the knowledge of topic and writing plans) and it is continued with the information in task environment (rhetorical problem and goal setting). The translating process is developed in each part of writing plan and consider to the use of correct sentences (grammar, vocabulary, punctuation, and so on). The last is reviewing related to re-reading, comprehending the text and editing. This method called as protocol (The Cognitive Process Model of the Composing Process).

Related to writing and cognitive process of writing, in fact most of students' faced writing difficulties. there are some previous study found the difficulties in writing as Hasan \& Marzuki (2017) analyzed the Indonesian EFL students' ability in writing by asking the students to do writing task in determined time. Their findings showed that the grammatical problems covering using plural forms, articles, verbs forms, clauses, passive voice and preposition existed on the students' writing.

Based on the students' difficulties in writing in general, actually students faced same problem in writing argumentative essay. It is caused by the complexity organization or argumentative essay. Freshman (2001) suggested that there are some stages in writing argumentative essay including, examine both sides of topic, writing thesis statement, writing topic sentence, writing introduction, writing counter argument, writing supporting paragraph and writing conclusion. From difficulties of writing elements and the organization of argumentative essay, it was opened the way for researcher to analysis the difficulties and offered the strategies for minimizing its difficulties.

The differences of previous study and this research is the researcher implement a strategy in teaching argumentative essay. The purpose of this research is to minimize students' difficulties in writing essay. The researcher identify students' difficulties in writing by interviewing them and using Arshi Strategy in teaching argumentative. Therefore, the major point to be highlighted in this study is "minimizing students' writing difficulties in writing essay through cognitive process. It is also implementing Arshi strategy in teaching writing and proposed solutions on students' writing difficulties. 


\section{LITERATURE REVIEW}

\section{Writing difficulties in Essay}

Morgan (2016) argues that the students are going to stuck when they want to begin their writing of the first idea or topic. In addition, according to Morgan, some issues students faced related to this is (1) they are confused to write the thesis statement that can be in the first or last sentence of the paragraph, (2) they must consider to what the audience or reader who read their essay also the purpose of the essay, (3) they are mostly in fear or failure while writing because of how they express their idea, feeling and experience. Clearly, as explained above there are various difficulties students face in writing an Essay. The issue become crucial to solve because the essay is a part of basic academic writing form. Wolfersberger (2003) also found that first language strategies may transfer to second language writing process. This is because of their habit which is happened naturally and it influenced their ability and performance of English writing.

\section{Strategies to minimize students' difficulties in writing essay Brainstorming strategy}

Fleming (2014) stated that brainstorming is a method that students can use to generate ideas for writing articles. During the brainstorming process, it should put any concerns about keeping order. The goal of is to write our ideas on paper without worrying about whether they make meaningful or how they fit together.

\section{Cognitive Process of Writing}

In cognitive process of writing, it was divided into three main parts including task environment, writers' long-term memory and writing process. Flowers and Hayes (1981) argue that the rhetorical problems divided into two parts consists of rhetorical situation and goal setting. First, rhetorical situation is focused on what the preparations are related to the task including understanding the task, questions, preparation and instruction. Second, goal setting refers to the writers' way in affecting and catching the readers' attention so that they want to read the text. It is important to begin the essay writing by using the real-world issue or reflect to the personal experience which is stated and formulated into the interesting statements. Scholars argued that the teaching writing is also divided into two parts including teachers' instruction and teacher's explanation. Both of them happened in the classroom setting. The teachers' instruction for the task is important for the students. It becomes the guidance for the students in doing the task. The teachers' instruction must be clear, explicit and logical. While, writers' long-term memory refers to how the writers stored the knowledge about the certain topic which given from the teachers and the lecturer or the topic they choose and how the writers have Essay plans including the ways in classifying them into some paragraphs of introduction, main and conclusion. The last is writing process which consists of pre writing, drafting and reviewing. Flowers and Hayes (1981) suggested that the three parts of writing process consists of planning, translating and reviewing. Planning refers to how the writers have a good plan for writing involves the topic and audience. Translating refers to how the writers in drafting or writing the whole of essay. Reviewing 
refers to how the writers' in checking the whole organization of essay. In planning, Al-maghrawy, (2012) defines brainstorming as consisting of general ideas related to the topic of writing. Therefore, brainstorming can guide students to write into a good form of writing. After brainstorming, it is continued with drafting or translating. This stage refers to how students write the first sentence in their essay writing to a complete essay. In drafting, Selvikavak, E. (2006) that the content of the opening paragraph is determined by converting the main idea into a question, finding the answer to the given main idea and writing the topic sentence. Christenson (2002) asserting that drafting is the process of getting ideas on paper. It means the students need a big effort to take appropriate idea for essay and how to organize it.Last, In reviewing, it was divided into two of peer review and teachers' review. First, it was peer review, Russell,et.al (2006) that refers to how students' controlling their activities of review through the whole essay. It is related to vocabularies, grammar, organization and idea of essay. Second, Coffin (2003) that teacher review where the teacher includes of the students' activities to review the students essay by giving feedback and correction.

\section{RESEARCH METHOD}

The research was qualitative method. The data were collected from interview, observation, questionnaire and students' essay. The research used semi structured interview to know more of students' difficulties in writing essay at English Department State University of Gorontalo Indonesia who at that time followed Writing English for Academic Purposes. The observation was conducted to find out the students' activities while learning essay in classroom related to their cognitive process. The last is students' essay to analyze the students' difficulties in essay and the quality of essay.

Creswell (2009) suggested there are six stages in analyzing qualitative data including organize and prepare the data for analysis, read through all the data, begin detailed analysis with a coding process, considering some remarks that will provide detailed guidance for the coding process, giving a description of data as a report and final step in data analysis involves making an interpretation or meaning of the data.

\section{FINDING AND DISCUSSION}

\section{Students' difficulties in writing essay}

This unit explained students' difficulties in writing an essay which consists of pre-writing, drafting and reviewing. First, pre writing indicate to prepare before beginning writing.

\section{Pre writing difficulties}

Data finding showed that students who difficult in pre writing, they were difficult to get the topic of essay because they did not have knowledge about certain issues and phenomenon happened nowadays. Besides, they also confused how to start to write essay at the beginning. Other case also found that, student were difficult in determining the audience and the goals of essay. The last difficulties were what strategies should do before write essay.Based on findings, 
Students' interview result as follow:

St 1 to 3 said "I difficult in pre-writing stage"

St 6 said "I feel confused about the goal of topic"

St 5 said "it was difficult in getting interesting topic"

St 9 said" it was difficult in finding a title of essay and thesis statement"

In addition, the results of student's thesis statements in essay, showed they difficult writing thesis statement as follow:

\begin{tabular}{|l|l|l|}
\hline Students & \multicolumn{1}{|c|}{ Thesis Statements } & \multicolumn{1}{c|}{ Notes } \\
\hline St 1 & $\begin{array}{l}\text { Technology is a means or system that functions to } \\
\text { provide comfort convenience to human. }\end{array}$ & $\begin{array}{l}\text { This thesis categorized too } \\
\text { general. It cannot be said as a } \\
\text { thesis statement, because } \\
\text { thesis contains of the main } \\
\text { sentence which cover the idea } \\
\text { to develop more. }\end{array}$ \\
\hline St 2 & $\begin{array}{l}\text { Students will think that homework is trivial because } \\
\text { they can paste it without having to think hard. }\end{array}$ & $\begin{array}{l}\text { This thesis categorized too } \\
\text { specific. It cannot be said as a } \\
\text { thesis statement, because it } \\
\text { describe a specific thing which } \\
\text { no need more explanation to } \\
\text { explore. }\end{array}$ \\
\hline St 3 & $\begin{array}{l}\text { Everything is completely digital. Everyone uses } \\
\text { technology to make jobs easier. }\end{array}$ & $\begin{array}{l}\text { This thesis categorized too } \\
\text { general. }\end{array}$ \\
\hline St 5 & $\begin{array}{l}\text { In this modern era cigarettes among teenagers. Even } \\
\text { though they know it dangerous but they still do it } \\
\text { without thinking about the dangerous. }\end{array}$ & $\begin{array}{l}\text { This thesis seems like an } \\
\text { argument position whether } \\
\text { support or claims the topic. It } \\
\text { can be said it is not a good } \\
\text { thesis statement. }\end{array}$ \\
\hline
\end{tabular}

It was supported by Morgan (2016) argues that the students are going to stuck when they want to begin their writing of the first idea or topic, they are confused to write the thesis statement that can be in the first or last sentence of the paragraph, they must consider to what the audience or reader who read their essay also the purpose of the essay, they are mostly in fear or failure while writing because of how they express their idea, feeling and experience. In the other words, the students have different difficulties for each stages in writing an essay. They also had different knowledge in writing. It is proved that between the result of interview and students' thesis statements were supported one to another. However, the results of students' thesis statements quoted from students' writing practice one. Second is drafting. It refers to what activity or things when the students write the essay. Data showed that they were difficult in organizing argumentative essay. In argumentative essay, it had specific text 
organization including (thesis statement, introduction, counter argument, supporting paragraph and concluding). Besides, they also difficult in aspects of writing involves grammar, vocabularies, cohesive, spelling and so on.

Students' interview result as follow:

St 4 said "it was difficult in writing by correct grammar and punctuation"

St 7said" it was difficult in drafting especially vocabularies"

St 8 said "I found difficulties in gathering idea for essay"

In addition, it was also supported the result of their essay as follow:

\begin{tabular}{|l|l|l|}
\hline Students & $\begin{array}{l}\text { Drafting difficulties (vocabulary, grammar, } \\
\text { punctuation and idea) }\end{array}$ & \multicolumn{1}{c|}{ Notes } \\
\hline St 4 & $\begin{array}{l}\text { Most everyone in the world are social media users. } \\
\text { Social media has the benefit of taking information } \\
\text { quickly. }\end{array}$ & $\begin{array}{l}\text { This sentence showed that } \\
\text { the student difficult in using } \\
\text { correct grammar and } \\
\text { punctuation. }\end{array}$ \\
\hline St 7 & $\begin{array}{l}\text { Cell phones in general has two impacts for the users } \\
\text { such as positive and negative impact. Athough cell } \\
\text { phones can make the user happy with it. }\end{array}$ & $\begin{array}{l}\text { This sentence showed that } \\
\text { the student have problem in } \\
\text { expressing his idea, because } \\
\text { of less of vocabularies and } \\
\text { the use of vocabularies } \\
\text { were not academic. }\end{array}$ \\
\hline St 8 & $\begin{array}{l}\text { Standardized test or National exam is one of way on } \\
\text { education to determine students' competency. Since } \\
\text { 1964 standardized test have been applied in } \\
\text { Indonesia about real applied without consider the } \\
\text { feedback from students. }\end{array}$ & $\begin{array}{l}\text { This sentence showed that } \\
\text { the student difficult in } \\
\text { arranging the idea, because } \\
\text { of many ideas comes in her } \\
\text { mind. She difficult whether } \\
\text { considering where is the } \\
\text { thesis statement and other } \\
\text { parts of essay. }\end{array}$ \\
\hline
\end{tabular}

This data were linked to Christenson (2002) asserting that drafting is the process of getting ideas on paper. It means the students need a big effort to take appropriate idea for essay and how to organize it. Besides, it also found that student were difficult to write the thesis statements, because they need to consider what idea or sentence which appropriate for thesis statements.

Third is reviewing. It refers to how students reviewed their essay as a whole. This case encourage students to be careful in examining the correctness of essay in all aspect of writing. As general, reviewing divided into two types including teacher review and peer review (students' review). Based 


\section{International Journal of Education and Social Science Research}

IJESSR

ISSN 2581-5148

Vol. 4, Issue.6, Nov-Dec 2021, p no. 63-76

on data, it was found that teacher gave students' feedback and correction for their essay. One of the data showed teacher said "Well, I check one of your friend's essays and we discuss it together. St 1 essay with the topic (technology has made us lazier), in this essay she wrote (people think that because everything has become......). From this sentence, it showed that she made mistake of grammar of words "that because". It should be eliminated because, the reason is because it made the form or pattern of Indonesian language. This case means the student transfer the idea from L1 to L2. This is incorrect, because both of the languages were different.

In addition, other data was found in St 10 essay as follow:

\begin{tabular}{|l|l|l|}
\hline \multicolumn{1}{|c|}{ Student } & $\begin{array}{l}\text { Difficult in reviewing part of } \\
\text { essay }\end{array}$ & \multicolumn{1}{c|}{ Notes } \\
\hline St 10 & $\begin{array}{l}\text { "Education is a learning } \\
\text { system to acquire knowledge } \\
\text { individually or in groups. It is } \\
\text { important for everyone } \\
\text { deserves an education.......... } \\
\text { “ }\end{array}$ & $\begin{array}{l}\text { These sentences showed that } \\
\text { the student was difficult in } \\
\text { reviewing her essay as a } \\
\text { whole. Whether to determine } \\
\text { thesis statement and other } \\
\text { writing elements like } \\
\text { grammar, vocabularies and } \\
\text { punctuation. }\end{array}$ \\
\hline
\end{tabular}

\section{Students' cognitive process of writing}

As cognitive process stages, researcher implementing Arshi strategy (including cognitive process way) in teaching argumentative. 


\section{International Journal of Education and Social Science Research}

IJESSR

ISSN 2581-5148

Vol. 4, Issue.6, Nov-Dec 2021, p no. 63-76

\section{Arshi strategy}

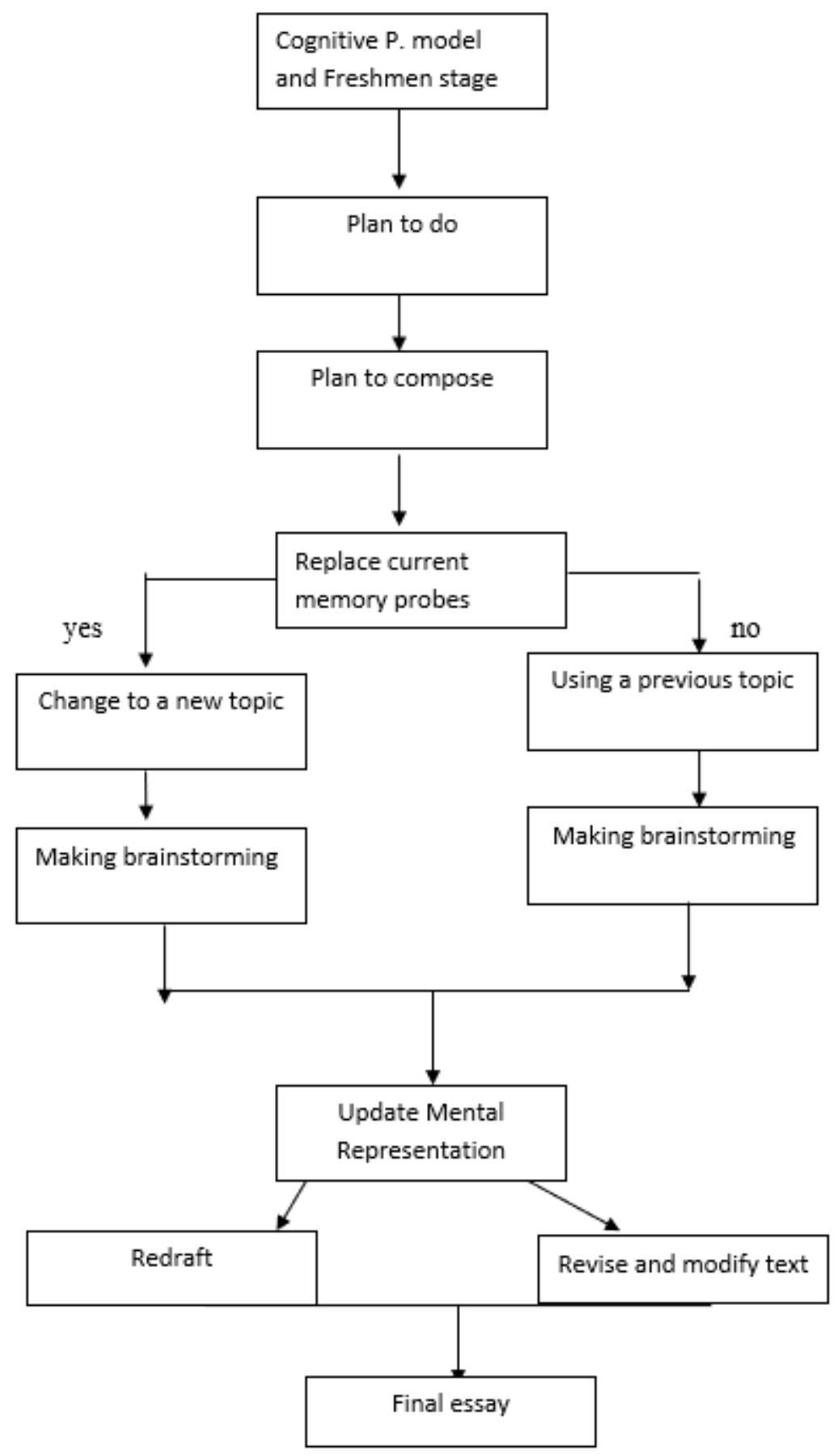

Stage 1 Cognitive P. model and Freshman 's stage 
At the beginning of activities, researcher used task environment part and Freshman's stages describe as follow:

1) The material was about argumentative essay, which discussed about "examine both of sides of a topic" in this meeting, the researcher explained about definition of argumentative essay, the function of the text and generic structure. In observing, researcher asked students to focus on the prompt which illustrate the issue. In questioning, Then, the researcher asked the students to have question related to the prompt. In experimenting, researcher engaged students to understand the prompt and provide reasons including (pro and cons). In associating, researcher asked students to decide position as the writer. Strategies to minimize students' difficulties in writing are build up students' focus and comprehension in analysing topic discuss and construct a new idea from the topic by using their own words.

\section{Stage 2 Plan to do}

In this stage, researcher gave chance for students to select topic and determine goals. The researcher asked them to select interest topic related to argumentative and determine what is the goal of the topic. During this stage, students focused in getting a good topic for them and decide its goals. They read some sources like articles related to the topic and understanding the topic. After getting the topic, students determine the goals of the topic. This way helped the students to paid attention to begin their writing.

Table 4.2 Students' topic and goal of essay

\begin{tabular}{|l|l|l|}
\hline Students & Topic & Goal \\
\hline St 1 & Technology has made us lazier & $\begin{array}{l}\text { To tell the readers the usage of } \\
\text { technology }\end{array}$ \\
\hline St 2 & Is Homework helpful or harmful & $\begin{array}{l}\text { To explain the readers impact of } \\
\text { homework }\end{array}$ \\
\hline St 3 & $\begin{array}{l}\text { Are we too dependent on } \\
\text { computers? }\end{array}$ & $\begin{array}{l}\text { To inform the readers about the } \\
\text { importance of computers in our } \\
\text { life }\end{array}$ \\
\hline
\end{tabular}

Goal setting is very motivating when done correctly (Reid and Lienemann, 2006). It means that effective goal requires students to understand the task and its purpose. Students understand what needs to be done, set goals help them let them continue to complete the task and controlling their progress while writing. Researcher applied this step to help them in guiding their writing and help them to understanding the writing task.

\section{Stage 3 Plan to compose}

In this stage, there are two activities including generate knowledge and produce text. Generate knowledge means students' have their own idea of topic as result of understanding the topic of text. 
To generate knowledge students, need to have more sources of reading. They focused on gaining more information and construct it become their own. While, to produce text, the students need to have the first plan in their mind before start to write.

Students' result of writing practice as follow:

\begin{tabular}{|c|c|c|}
\hline Students & Practice I & Practice II \\
\hline St 6 & 61 & 53 \\
\hline St 9 & 66 & 72 \\
\hline St 10 & 61 & 66 \\
\hline
\end{tabular}

From this table, it is indicates that students' essay quality are influenced to how many books they read to get idea for essay. In addition, the understanding of texts they read will help them in exploring more idea and enrich their vocabularies for writing. After that, they create a new idea from reading and start to plan for writing. This stage was supported by Chettri and Rout (2013), reading habits are the number of books being read. Similarly, Wagner et al. (2002) describe reading habits reflected how far the materials learned and more times spend to analyze texts.

Strategy to minimize students' difficulties in writing is to guide them to have a new habit of more reading scientifically. Researcher guide them to have reading routine before started to write to help them in exploring idea and be more critique in analyzing reading context around them. For example, the current issues or phenomenon right now.

\section{Stage 4 Replace current memory probes}

In this stage, there are two choices of (yes if it continue with a new topic) and (no if it continue with a previous topic). Students change their topic if they think or feel, it should be replace or not. This stage aim to confirm their idea that should be consistent. In fact, students are ready with their topic, therefore they continue with the previous topic. Strategy to minimize students' difficulties in writing is to encourage them focus on what they read and prepare for the writing plan.

\section{Stage 5 brainstorming}

In this stage, researcher asked students to make brainstorming. Brainstorming contains of what the main idea they have after reading. In data finding, all of the students' making the brainstorming for each writing activities like while learning and practicing. Thorne (1993) also emphasized that the most important technique to do in the beginning of writing is pre- writing. For many writers, only starting to write is the difficult part to write. It takes a lot of time and attention on dictionary writing to solve the problem of "writer's block". In data showed that students said that "it was difficult to find interesting topic". In classroom, students follow the research instruction to make a brainstorming. They have at least three to five idea in brainstorming. It was also supported to Fleming (2014) that 
brainstorming is a method that students can use to generate ideas for writing articles. During the brainstorming process, it should put any concerns about keeping order. The goal of is to write our ideas on paper without worrying about whether they make meaningful or how they fit together.

Strategy to minimize students' difficulties in writing is to create a writing habit by making brainstorming as pre writing and encourage them to be active in reading many sources to develop idea for writing.

\section{Stage 6 Update mental representation}

In this stage, students need to recheck the whole essay including the text organization (Introduction: hook, thesis statement and topic sentence, Body of paragraph: counter argument and supporting paragraph and conclusion). Then, the linguistics elements (grammar, vocabularies, punctuation and coherence). In classroom, researcher gave them time to recheck their essay and discuss together. Researcher took some examples of them to check. In correcting students' writing, researcher give instruction to them for helping them to know their correct or incorrect usage of writing elements and organization of essay. In this stage emphasize to researcher and students' role in writing classroom. Harmer (2007) explained the roles of teacher in providing material for learning which understandable, select an appropriate task and giving suggestion for the learning. While students are able to give their responses or feedback from teacher's instruction. Data showed that students followed the instruction from researcher as teacher and do the task regularly. Strategy to minimize students' difficulties in writing is guiding students' to be aware about argumentative essay organization and the correct usage of linguistics elements.

\section{Stage 7 Revise and modify text}

In this stage, students' need to revise some mistaken from the essay. Students need to pay attention to whole essay. This stage covered two activities of drafting and reviewing. For drafting, it gives chanced for students to re write into a correct usage of writing elements and organization of essay and reviewing to help students in controlling their essay as a whole. This stage supported by Russell,et.al (2006) that refers to how students' controlling their activities of review through the whole essay. It is related to vocabularies, grammar, organization and idea of essay. Besides, in this stage also represented the drafting activities to re-write the correct form. It is supported by Selvikavak, E. (2006) that the content of the opening paragraph is determined by converting the main idea into a question, finding the answer to the given main idea and writing the topic sentence. In classroom, students focus on their essay and checking the correctness.

Strategy to minimize students' difficulties is guide students to understand the correct usage of linguistic elements and how to check the correct idea in argumentative essay (introduction, body of paragraph and conclusion) 


\section{Stage 8 redraft (modify plan and text)}

This stage is a choice for students, because they can or cannot redraft their essay. this stage is very hard and spending much time. Students must work hard and started from beginning ( modify plan) and write the essay.

In fact, there is no students did this stage. They focused on what they have written in first topic they choose.

\section{Stage 9 Final essay}

This stage is a final stage where the students complete their essay and it is ready to get the score. The quality of this essay as the reference to categorize students' essay good or poor one.

As finding of students' difficulties in writing essay at previous page, there are some strategy used in minimizing students' difficulties in writing essay by Arshi Strategy (combination of cognitive process, reading and writing habits) as follow:

\begin{tabular}{|l|l|l|}
\hline \multicolumn{1}{|c|}{ Students } & $\begin{array}{c}\text { Part of difficulties in writing } \\
\text { essay }\end{array}$ & Arshi Strategy to minimize it \\
\hline $\begin{array}{l}\text { St 1, St 2, St 3, St, 5, St 6, and } \\
\text { St 9 }\end{array}$ & Pre writing & $\begin{array}{l}\text { By using stage 5 } \\
\text { (Brainstorming) }\end{array}$ \\
\hline St 4, St 7 and St 8 & Drafting & $\begin{array}{l}\text { By using stage 7 (revise and } \\
\text { modify text) }\end{array}$ \\
\hline St 10 & Reviewing & $\begin{array}{l}\text { By using stage 6 (update } \\
\text { mental representation and 7 } \\
\text { (revise and modify text) }\end{array}$ \\
\hline
\end{tabular}

\section{CONCLUSION AND SUGGESTION}

\section{Conclusion}

a) Students' difficulties in writing essay may influences by some factors including cognitive process. Students' difficulties may influence by cognitive process in terms of how students getting started to write the essay. Students' need to have prior knowledge by reading many sources and take one topic to be their own.

b) The strategy used in this research can be the reference for teachers or lecturers in teaching essay. The strategy covered detail stages to guide students in composing essay.

c) This research proved that students' difficulties in writing essay can be minimized through cognitive process. By cognitive process, students can prepare themselves in learning essay through the stages of cognitive are task environment, writers' long-term memory and writing process. 
Vol. 4, Issue.6, Nov-Dec 2021, p no. 63-76

\section{Suggestion}

This research suggested to the next research be explored more about other factors may influence students' difficulties in writing essay in terms of age, gender and personality of learners. In addition, the further research may create a new strategy based on the factors above.

\section{REFERENCES}

Al-maghawry, A. (2012). Effectiveness of Using the Brainstorming Technique to Learn Some Basic Skills and Collection of Knowledge for Beginners in Volleyball. World Journal of Sport Sciences 6 (4): $361-366$

Coffin, C., Curry, M. J., Goodman, S., Hewings, A., Lillis, T. M., \& Swan, J. (2003). Teaching Academic Writing A toolkit for highe

Creswell (2009) Research design of qualitative, quantitative and mix methods approaches by SAGE Publications, In

Chettri, K., \& Rout S. K. (2013). Reading habits - An overview. IOSR Journal of Humanities and Social Science (IOSR-JHSS), 14(6),13-17. Retrieved from www.Iosrjournals.Org

Christenson, S. L., \& Anderson, A. R. (2002). Commentary: The centrality of the learning context for students' academic enabler skills. School Psychology Review, 31, 378 - 393.

Flower and Hayes (1981). A Cognitive Process Theory of Writing. College Composition and Communication, 365-387.

Fleming (2014). Brainstorming Techniques For Left Brains and Right Brains

Harmer, Jeremy. (2007). How to Teach English. Edinburgh: Pearson Education Limited.

Hasan, J., \& Marzuki, M. (2017). An Analysis of Student's Ability in Writing at Riau University Pekanbaru. Theory and Practice in Language Studies, 7(5), 380-388

Morgan,K. (2016) Problems That Students Encounter With Essay Writing.Retrieved from January 4, 2017 from http://classroom.synonym.com/problems-students-encounter-essay-writing-2070.html

Reid, R., \& Lienemann, T 0. (2006). Strategy instruction for students with learning disabilities. New York: Guilford Press

Russell, A. A. (2006). Calibrated Peer Review: A Writing and

Critical-Thinking Instruction Tool. Retrieved from www.aaas.org/publication/books-reports/CCLI/PDFs/03-

Sucpeds-russell

Selvikavak, E. (2006). Advanced Level in Teaching Turkish as a Foreign Language.An Ap 


\section{International Journal of Education and Social Science Research}

Vol. 4, Issue.6, Nov-Dec 2021, p no. 63-76

plication on Developing Students' Paragraph Writing Skill. University Institute of Social Sciences, Ankara.

Thorne S (1993). Prewriting: A basic skill for basic writers. Teaching English in the Two-Year College 20(1):31-36

Wagner, S. (2002). The reading habits of teams. Journal of Reading Today, 46, 3-4

Wolfersberger, Mark. (2003). L1 to L2 Writing Process and Strategy Transfer: A Look at Lower proficiency Writers. TESL-EJ, 7, 2. Retrsieved January 26, 2017, from

http://writing.berkeley.edu/TESL-EJ/ej26/ababs.html 